\title{
HUBUNGAN FUNGSI AGIL DENGAN KESEJAHTERAAN KELUARGA NELAYAN YANG RAWAN TERKENA BENCANA ALAM
}

\author{
The Correlation between AGIL (Adaptation, Goal Attainment, Integration, and Latency) \\ Functions and Family Welfare of Fishermen in Disaster Area
}

\author{
EUIS SUNARTI ${ }^{1 *}$, IRNI RAHMAYANI JOHAN ${ }^{1}$, CHRISTINE HARYATI $^{2}$ \\ ${ }^{1}$ Staf Pengajar Departemen IImu Keluarga dan Konsumen, Fakultas Ekologi Manusia, \\ Institut Pertanian Bogor, Jalan Lingkar Kampus IPB Dramaga, \\ Bogor 16680 \\ ${ }^{2}$ Departemen Ilmu Keluarga dan Konsumen, Fakultas Ekologi Manusia, Institut Pertanian \\ Bogor, Kampus Dramaga, Bogor 16680
}

\begin{abstract}
The objectives of this study were to analyze family welfare (categorized as objective and subjective welfare) of fishermen and its correlation with family AGIL (adaptation, goal attainment, latency, and integration) functions. The study design was cross sectional. Data were collected in 2009 in Pangandaran District, Ciamis Regency (affected by tsunami in 2006), taken from 80 families (53 categorized as juragan and 27 as janggol) as the samples selected by using proportional random sampling method. By using spearman's correlation test, it was found that there was a positive correlation between family AGIL functions and family welfare. Moreover the results of correlation test between components of family AGIL and family welfare showed that there were positive correlations between adaptation function and objective welfare, and between latency function with subjective welfare. This means that the higher the family adaptation, the higher the family income, and the better the level of family latency, the higher the level of family subjective welfare. Descriptive analysis revealed that the essential components of fishermen family subjective welfare included sincere feeling, i.e., always thank God for whatever happen and have a good satisfaction even in marginal family condition. The above results implied that, increasing family AGIL function should become a crucial factor in increasing family welfare. Indeed, strengthening family program should be emphasized on the two vital functions: adaptation and latency.
\end{abstract}

Key words: family welfare, adaptation, goal attainment, integration, latency

\section{PENDAHULUAN}

Indonesia merupakan negara kepulauan yang wilayah lautannya lebih luas dibandingkan wilayah daratannya dengan garis pantai sepanjang $81.000 \mathrm{~km}$. Wilayah perairan Indonesia berada diantara dua lempeng yaitu lempeng samudera dan lempeng benua. Secara teknis, kondisi demikian menyebabkan sebagian besar kawasan pesisir dan pulau-pulau kecil di Indonesia berada pada daerah rawan bencana alam seperti gempa bumi, tsunami, gelombang pasang, erosi pantai, banjir pasang-surut dan subsiden, badai, dan sedimentasi. Padahal banyak masyarakat Indonesia yang tinggal di sepanjang pantai dengan mata pencaharian utamanya nelayan, dan proporsi terbesarnya adalah nelayan buruh (janggol) dengan tingkat kesejahteraan keluarga yang rendah.

Berdasarkan hal tersebut menjadi penting upaya peningkatan resiliensi keluarga, khususnya di wilayah rawan bencana. Sebagaimana Sunarti (2007) menunjukkan besarnya perubahan, tantangan, dan ancaman yang dihadapi keluarga pada saat ini. Resiliensi keluarga merupakan kemampuan keluarga untuk bangkit dari keterpurukan dan krisis, terkait erat dengan kemampuan keluarga mempertahankan keberlangsungan hidup keluarganya pada keadaaan apapun dengan memaksimalkan pengelolaan sumberdaya keluarga. Sementara itu menurut Parson dalam Hamilton (1983) sebuah sistem dapat mempertahankan keberlangsungannya manakala menjalankan fungsi adaptasi (A), pencapaian tujuan ( $\mathrm{G}=$ goal attainment), 
integrasi (I=integration), dan pemeliharaan sistem (L=latency), atau dikenal dengan "AGIL".

Berdasarkan latar belakang tersebut, penelitian ini bertujuan untuk menganalisis keberfungsian dan pola hubungan antar fungsi AGIL pada nelayan sebagai dasar rekomendasi program peningkatan kelentingan (relisience) atau penurunan kerentanan (vulnerability) nelayan sebagai bagian program pengurangan risiko bencana. Adapun tujuan khususnya adalah untuk: (1) menggambarkan karakteristik keluarga, dukungan sosial, akses informasi, keberfungsian keluarga AGIL dan kesejahteraan keluarga; (2) menganalisis hubungan antara fungsi AGIL dengan karakteristik keluarga, dukungan sosial, dan kesejahteraan keluarga; (3) menganalisis pola hubungan antar fungsi adaptasi, penetapan tujuan, integrasi, dan pemeliharaan sistem keluarga; (4) membedakan fungsi AGIL antara keluarga juragan dan keluarga buruh (selanjutnya disebut janggol).

\section{METODE}

Desain, Lokasi, dan Waktu

Desain yang digunakan pada penelitian adalah cross sectional. Penelitian dilaksanakan di Desa Pangandaran, Kecamatan Pangandaran, Kabupaten Ciamis, pada bulan Maret 2006 selama dua minggu.

\section{Cara Penarikan Contoh}

Penelitian ini melibatkan 80 contoh keluarga nelayan yang terkena bencana. Contoh dipilih dengan menggunakan metode proportional random sampling. Contoh terdiri atas 53 juragan dan 27 janggol.

\section{Pengolahan dan Analisis Data}

Data yang dikumpulkan meliputi karakteristik keluarga, fungsi AGIL, dukungan sosial, dan kesejahteraan keluarga. Data yang menggambarkan kondisi sebelum bencana dikumpulkan dengan metode retrospektif. Data diolah menggunakan Microsoft Excel, SPSS for Windows, dan Minitab for Windows. Data selanjutnya dianalisis secara deskriptif dan statistik inferensia menggunakan uji independent sample t-test dan MannWhitney serta analisis korelasi Rank Spearman.

\section{HASIL DAN PEMBAHASAN}

\section{Karakteristik Keluarga, Akses Informasi, dan Dukungan Sosial}

Contoh penelitian memiliki anggota keluarga berkisar 2 sampai 8 orang, dimana proporsi terbesar juragan maupun janggol memiliki ukuran keluarga kecil ( $\leq 4$ orang). Persentase terbesar contoh berada dalam kisaran usia produktif. Hampir tiga perempat juragan demikian juga istrinya $(73,6 \%$ dan $74,5 \%$ ) berpendidikan kurang dari 9 tahun, namun hanya dua pertiga janggol dan juga istrinya $(66,67 \%)$ yang berpendidikan kurang dari 9 tahun. Rata-rata pendapatan/kapita/ bulan keluarga juragan Rp 1.191.015,00, dan keluarga janggol $\operatorname{Rp} 513.018,00$. Seluruh keluarga juragan dan sebagian besar keluarga janggol $(81,48 \%)$ memiliki aset lebih dari atau sama dengan 3 kali kebutuhan minimum per bulan.

Keluarga juragan lebih mudah memperoleh informasi daripada keluarga janggol. Sebagian besar keluarga juragan dan keluarga janggol memperoleh informasi dari TV, tidak ada juragan dan janggol yang mengakses informasi dari surat kabar. Informasi yang banyak diperoleh adalah mengenai keadaan cuaca. Akses informasi, sumber informasi, jenis informasi yang dimiliki keluarga juragan (64,15\%) dan keluarga janggol $(66,67 \%)$ berada pada kategori sedang.

Dukungan sosial yang diterima keluarga berasal dari keluarga luas, tetangga, dan lembaga masyarakat dan atau pemerintah. Lebih dari tiga perempat keluarga juragan dan janggol menerima dukungan sosial yang tinggi dari keluarga luas dan dari tetangga. Sementara itu persentase keluarga juragan yang menerima dukungan sosial yang tinggi dari lembaga masyarakat/pemerintah, dua kali lebih besar $(60,4 \%)$ dibandingkan keluarga janggol (26\%). Hal ini dikarenakan juragan mendapatkan bantuan dan fasilitas yang baik ketika terjadi bencana. Sebagian besar keluarga juragan dan keluarga janggol tidak mengalami perubahan dukungan sosial yang diterima dari keluarga luas, tetangga, dan lembaga masyarakat/pemerintah antara sebelum dengan sesudah terjadi bencana alam.

\section{Fungsi $A G I L$}

Fungsi Adaptasi. Tindakan adaptasi keluarga yang dilakukan berupa pencarian nafkah ganda, untuk mengatasi masalah ekonomi keluarga. Persentase terbesar 
contoh melakukan satu tindakan adaptasi, yakni dilakukan oleh sebanyak 32,08\% keluarga nelayan juragan dan 25,93\% nelayan buruh. Berdasarkan hasil uji beda, tidak terdapat perbedaan yang signifikan antara banyaknya tindakan adaptasi yang dilakukan keluarga nelayan juragan dan keluarga nelayan buruh. Sebaran contoh menurut banyaknya tindakan adaptasi disajikan pada Tabel 1. Dalam penelitian ini diasumsikan bahwa semakin banyak tindakan adaptasi yang dilakukan, maka kemampuan untuk meningkatkan kesejahteraan keluarga semakin tinggi.

Tabel 1. Sebaran contoh (\%) menurut banyaknya tindakan adaptasi

\begin{tabular}{|c|c|c|}
\hline Tindakan Adaptasi & Juragan & Janggol \\
\hline 0 tindakan & 26,42 & 22,22 \\
\hline 1 tindakan & 32,08 & 25,93 \\
\hline 2 tindakan & 16,98 & 22,22 \\
\hline 3 tindakan & 11,32 & 11,11 \\
\hline 4 tindakan & 7,55 & 11,11 \\
\hline 5 tindakan & 5,66 & 7,41 \\
\hline Total & 100,00 & 100,00 \\
\hline$p$-value & \multicolumn{2}{|c|}{0,4488} \\
\hline
\end{tabular}

Tindakan adaptasi yang paling banyak dilakukan juragan maupun janggol adalah menambah jadwal melaut, membuat dan menjual ikan asin, dan janggol bangunan serta bidang jasa (Tabel 2). Sebagian besar keluarga contoh tidak mengalami perubahan pencarian nafkah dalam keluarga sebelum dan sesudah terjadi bencana alam. Hal ini disebabkan karena tidak adanya perubahan

Tabel 2. Sebaran contoh (\%) menurut pencarian nafkah yang dilakukan selama musim paceklik

\begin{tabular}{lrr}
\hline Jenis Pencarian Nafkah & Juragan & Janggol \\
\hline Buruh bangunan & 13,21 & 25,93 \\
Menambah jadwal melaut & 28,30 & 25,93 \\
Membuat dan jual ikan asin & 16,98 & 7,41 \\
Menarik becak & 3,77 & 7,41 \\
Buruh tani & 1,89 & 3,70 \\
Jahit & 1,89 & 0,00 \\
Ojek laut & 1,89 & 0,00 \\
Buruh pembuat cindera & 1,89 & 0,00 \\
mata & 9,43 & 18,52 \\
Warung & & \\
\hline
\end{tabular}

kondisi dan keadaan di lokasi penelitian sebelum dan sesudah terjadi bencana alam. Berdasarkan hasil uji beda, tidak terdapat perbedaan yang signifikan antara perubahan adaptasi keluarga contoh sebelum dan sesudah terjadi bencana alam pada keluarga nelayan juragan dan keluarga nelayan buruh.

Fungsi Pencapaian Tujuan. Sebaran juragan dan nelayan menurut jumlah tujuan keluarga dan menurut aspek ekonomi, pendidikan anak, dan agama disajikan pada Tabel 3. Persentase juragan maupun janggol memiliki tujuan yang lebih banyak pada aspek ekonomi dibandingkan pendidikan anak dan agama. Hal tersebut menunjukkan aspek ekonomi merupakan fokus tujuan keluarga terkait permasalahan ekonomi keluarga. Namun demikian hasil uji beda menunjukkan tidak terdapat perbedaan tujuan antara juragan dan janggol pada ketiga aspek tersebut.

Fungsi Integrasi. Terdapat 2 sampai 4 tindakan integrasi yang dilakukan sebagian besar juragan maupun janggol, sehingga menyebabkan tidak terdapat perbedaan tindakan integrasi pada kedua kelompok tersebut (Tabel 4). Tidak terjadi perubahan jumlah tindakan integrasi dalam keluarga sebelum dan sesudah terjadi bencana alam, namun terjadi perbaikan kualitas tindakan integrasi yang dilakukan oleh kedua kelompok contoh antara sebelum dan sesudah bencana.

Fungsi Pemeliharaan Sistem. Pemeliharaan sistem keluarga dilakukan baik oleh suami (kepada istri), oleh istri (kepada suami), dan oleh orangtua (kepada anak), sebagaimana hasilnya disajikan pada Tabel 5. Tidak terdapat perbedaan fungsi pemeliharaan sistem suami (kepada istri) dan orangtua (kepada anak) antara juragan dan janggol, namun pemeliharaan sistem yang dilakukan istri juragan berbeda nyata dan lebih baik dibandingkan istri janggol. Hasil analisis menunjukkan bahwa sebagian besar keluarga juragan dan janggol tidak mengalami perubahan dalam memelihara sistem keluarga sebelum dan sesudah terjadi bencana alam. 
Tabel 3. Sebaran contoh (\%) menurut banyaknya tujuan yang ingin dicapai

\begin{tabular}{|c|c|c|c|c|c|c|}
\hline \multirow{2}{*}{ Tujuan yang ingin Dicapai } & \multicolumn{2}{|c|}{ Ekonomi } & \multicolumn{2}{|c|}{ Pendidikan Anak } & \multicolumn{2}{|c|}{ Agama } \\
\hline & Juragan & Janggol & Juragan & Janggol & Juragan & Janggol \\
\hline 1 tujuan & 9,43 & 3,70 & 15,09 & 22,22 & 11,32 & 11,11 \\
\hline 2 tujuan & 11,32 & 7,41 & 16,98 & 3,70 & 26,42 & 14,81 \\
\hline 3 tujuan & 9,43 & 3,70 & 37,74 & 48,15 & 41,51 & 51,85 \\
\hline 4 tujuan & 24,53 & 22,22 & 30,19 & 25,93 & 20,75 & 22,22 \\
\hline 5 tujuan & 35,85 & 37,04 & 0,00 & 0,00 & 0,00 & 0,00 \\
\hline 6 tujuan & 9,43 & 25,93 & 0,00 & 0,00 & 0,00 & 0,00 \\
\hline Total & 100,00 & 100,00 & 100,00 & 100,00 & 100,00 & 100,00 \\
\hline p-value & \multicolumn{2}{|c|}{0,0460} & \multicolumn{2}{|c|}{0,8933} & \multicolumn{2}{|c|}{0,4892} \\
\hline
\end{tabular}

Tabel 4. Sebaran contoh (\%) menurut banyaknya tindakan integrasi

\begin{tabular}{crr}
\hline Tindakan Integrasi & Juragan & Janggol \\
\hline 1 tindakan & 1,87 & 0,00 \\
2 tindakan & 28,30 & 25,93 \\
3 tindakan & 30,19 & 29,63 \\
4 tindakan & 30,19 & 37,04 \\
5 tindakan & 9,43 & 7,41 \\
\hline Total & 100,00 & 100,00 \\
\hline p-value & \multicolumn{2}{c}{0,6982} \\
\hline
\end{tabular}

Tabel 5. Sebaran contoh (\%) menurut banyaknya tindakan pemeliharaan sistem

\begin{tabular}{|c|c|c|}
\hline $\begin{array}{l}\text { Tindakan Pemeliharaan } \\
\text { Sistem }\end{array}$ & Juragan & Janggol \\
\hline \multicolumn{3}{|c|}{ Dimensi pemeliharaan yang dilakukan suami } \\
\hline 1 tindakan & 0,00 & 3,70 \\
\hline 2 tindakan & 28,30 & 29,63 \\
\hline 3 tindakan & 30,19 & 44,44 \\
\hline 4 tindakan & 41,51 & 22,22 \\
\hline Total & 100,00 & 100,00 \\
\hline p-value & \multicolumn{2}{|c|}{0,1709} \\
\hline \multicolumn{3}{|c|}{ Dimensi pemeliharaan yang dilakukan istri } \\
\hline 1 tindakan & 5,66 & 44,44 \\
\hline 2 tindakan & 9,43 & 7,41 \\
\hline 3 tindakan & 54,72 & 25,93 \\
\hline 4 tindakan & 30,19 & 22,22 \\
\hline Total & 100,00 & 100,00 \\
\hline p-value & \multicolumn{2}{|c|}{0,0051} \\
\hline \multicolumn{3}{|c|}{$\begin{array}{l}\text { Dimensi pemeliharaan yang dilakukan orangtua } \\
\text { terhadap anak }\end{array}$} \\
\hline 1 tindakan & 32,08 & 25,93 \\
\hline 2 tindakan & 16,98 & 18,52 \\
\hline 3 tindakan & 28,30 & 29,63 \\
\hline 4 tindakan & 22,64 & 25,93 \\
\hline Total & 100,00 & 100,00 \\
\hline p-value & \multicolumn{2}{|c|}{0,6127} \\
\hline
\end{tabular}

\section{Kesejahteraan Keluarga}

Kesejahteraan keluarga dibagi menjadi kesejahteraan objektif dan subjektif. Pertama, kesejahteraan objektif diukur melalui indikator utama (pendapatan keluarga) dan indikator tambahan (pemenuhan kebutuhan pokok). Hasil analisis menunjukkan kesejahteraan objektif contoh berbeda menurut musim. Pada musim panen, hampir seluruh keluarga (juragan dan janggol) terkategori tidak miskin, namun hal sebaliknya terjadi pada musim paceklik. Pada musim biasa, sebanyak 56,6\% keluarga juragan terkategori tidak miskin sedangkan $48,15 \%$ keluarga janggol terkategori sangat miskin. Kedua, hasil analisis kesejahteraan subjektif menunjukkan bahwa persentase terbesar keluarga juragan dan janggol terkategori sejahtera, sehingga hasil uji beda menunjukkan tidak terdapat perbedaan yang signifikan pada peubah kesejahteraan subjektif antara keluarga juragan dan keluarga janggol.

\section{Hubungan antar Peubah Penelitian}

Gambar-gambar berikut ini merupakan hasil uji korelasi bivariat yang signifikan $(p<0,001 ; p<0,01 ; p<0,05)$, dipetakan untuk memudahkan dalam analisis dan pemaknaan, kesimpulan dan saran, atau rekomendasi hasil penelitian. Hasil uji hubungan meliputi hubungan antara karakteristik keluarga, akses informasi, dukungan sosial dengan fungsi $A G I L$ (Gambar 1), hubungan antara karakteristik keluarga dengan kesejahteraan (Gambar 2), pola hubungan antara fungsi AGIL (Gambar 3 ), dan hubungan antara fungsi $A G I L$ dengan kesejahteraan (Gambar 4). 


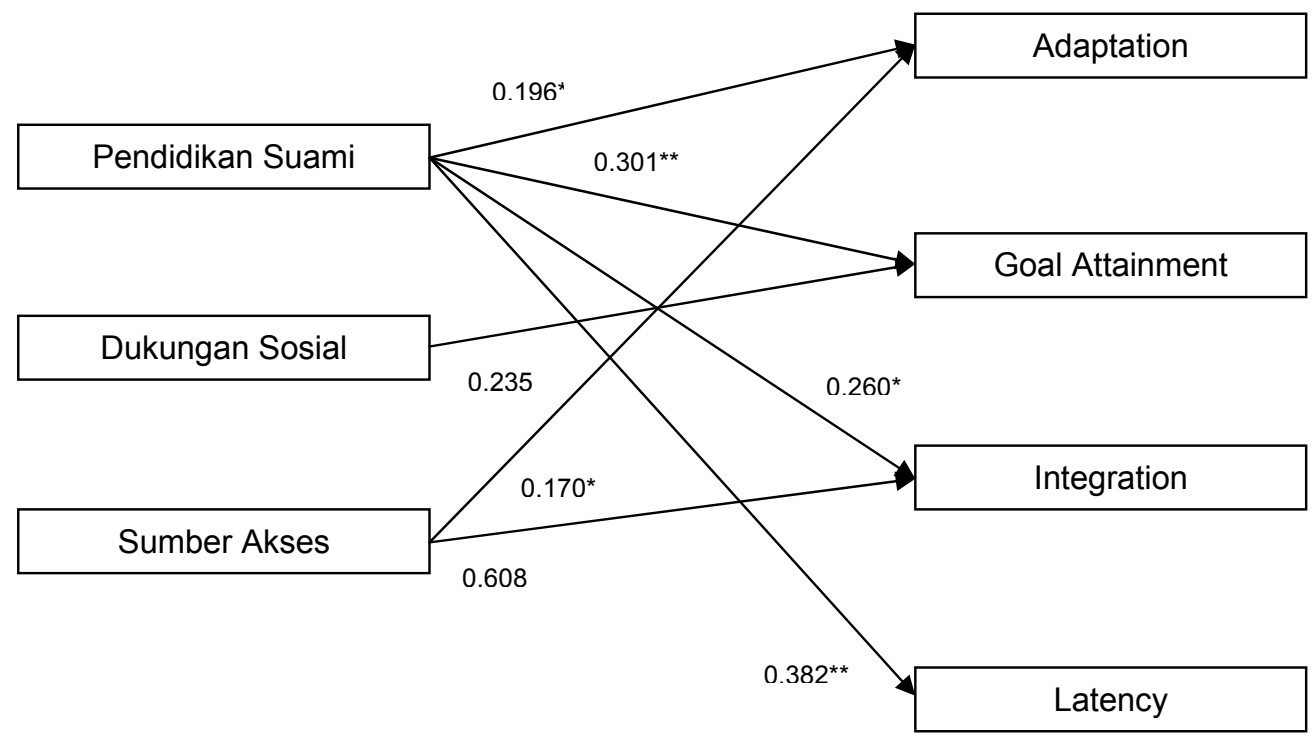

Gambar 1. Pemetaan hasil korelasi bivariat antara karakteristik keluarga, dukungan sosial, akses informasi, dengan fungsi $A G I L$

Hasil korelasi menunjukkan bahwa semakin lama pendidikan suami semakin baik fungsi adaptasi, pencapaian tujuan, integrasi, dan pemeliharaan sistem keluarga; semakin baik dukungan sosial semakin baik pencapaian tujuan keluarga, dan semakin baik akses informasi semakin baik tindakan adaptasi dan integrasi keluarga. Hal ini diduga karena tingginya tingkat pendidikan suami maka cara berpikirnya akan semakin baik sehingga mampu mengajarkan anggota keluarganya untuk dapat menjalankan peran dan fungsinya masing-masing di dalam keluarga. Sementara itu hasil korelasi antara karakteristik keluarga dengan kesejahteraan keluarga menunjukkan bahwa lama pendidikan suami, lama pendidikan istri, dan akses informasi yang dilakukan keluarga berkorelasi positif baik dengan kesejahteraan objektif maupun dengan kesejahteraan subjektif keluarga (Gambar 2). Semakin banyak akses informasi, sumber informasi, dan jenis informasi yang diperoleh maka semakin tinggi pula pendapatan per kapita keluarga. Hal ini diduga karena semakin banyak akses informasi, sumber informasi dan jenis informasi yang diperoleh keluarga, maka semakin tinggi kemampuan keluarga untuk mengelola sumberdaya yang dimilikinya yang dapat menambah pendapatan keluarga. Hasil analisis juga menunjukkan semakin besar jumlah anggota keluarga semakin rendah kesejahteraan objektif keluarga.
Pola hubungan antara fungsi $A G I L$ pada penelitian ini ditunjukkan pada Gambar 3a. Pola tersebut berbeda dengan hasil penelitian serupa pada keluarga petani seperti yang tersaji pada Gambar 3b (Sunarti et al. 2009). Hasil analisis tidak menunjukkan hubungan antara adaptasi dengan penetapan tujuan, sehingga terdapat dua kemungkinan pola hubungan yaitu " $A-L G l$ " atau "GIL-A" yang menekankan adaptasi atau penetapan tujuan sebagai fungsi yang mendorong fungsi lainnya. Pola GIL-A mengasumsikan bahwa jumlah tujuan yang ingin dicapai keluarga mendorong fungsi integrasi dan pemeliharaan sistem, dimana: (1) semakin banyak tujuan yang ingin dicapai, semakin baik tindakan integrasi dan pemeliharaan sistem, (2) terdapat hubungan positif antara tindakan integrasi dan pemeliharaan sistem keluarga, dan (3) semakin banyak tindakan adaptasi maka semakin baik pemeliharaan sistem keluarga. Sedangkan pola "A-LGl" menekankan tindakan adaptasi sebagai pendorong fungsi pemeliharaan sistem yang kemudian berkorelasi dengan fungsi integrasi dan tindakan adaptasi. Hasil tersebut berbeda dengan hasil penelitian pada keluarga petani menunjukkan pola "AGIL" dimana tindakan adaptasi menjadi pendorong penetapan tujuan keluarga, kemudian diikuti tindakan integrasi dan pemeliharaan sistem. 



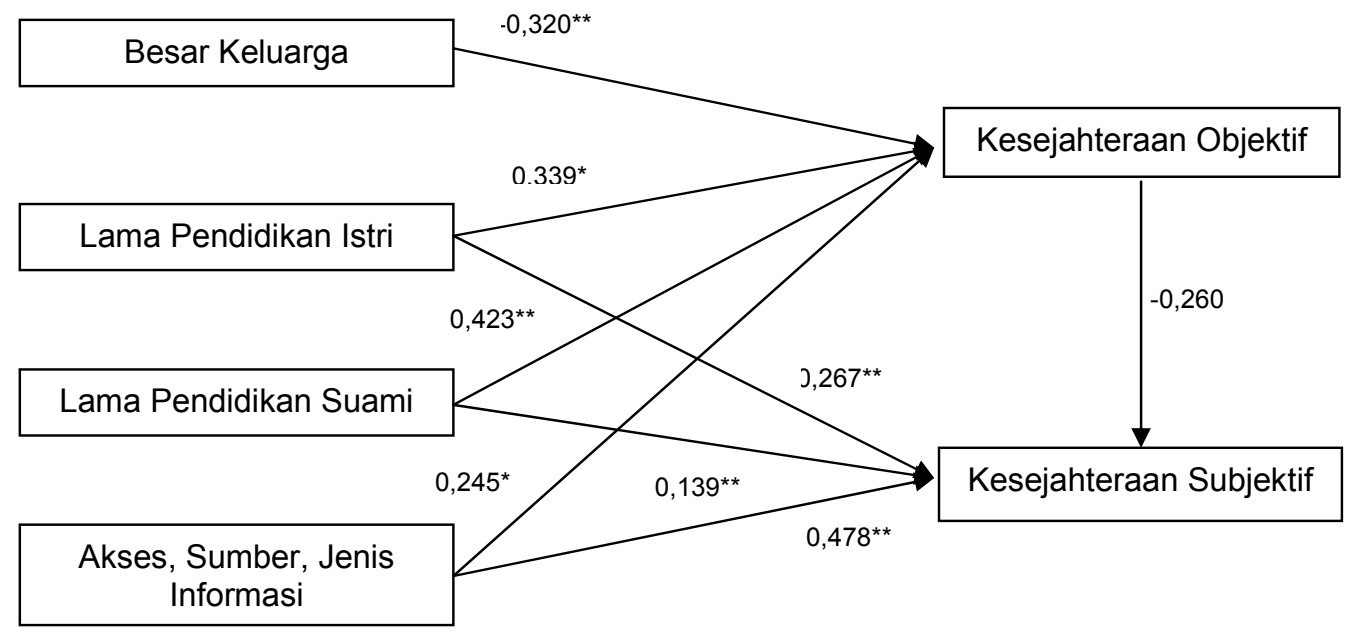

Gambar 2. Pemetaan hasil korelasi bivariat antara karakteristik keluarga, dukungan sosial, akses informasi, dengan kesejahteraan keluarga

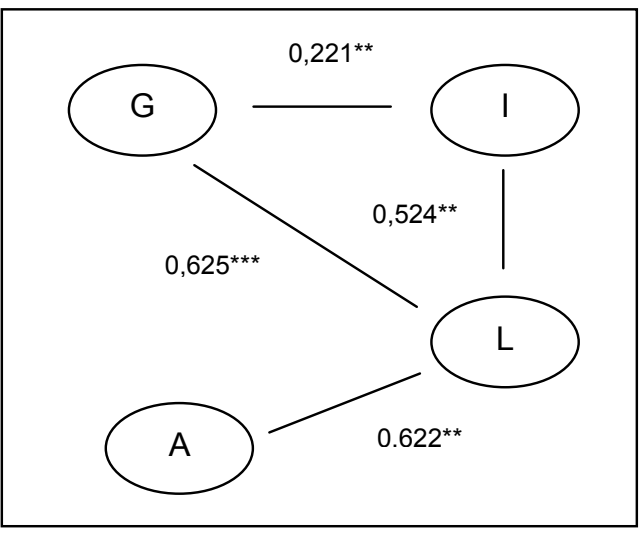

Gambar 3a. Pola hubungan antar fungsi AGIL keluarga nelayan

Hasil analisis korelasi antara fungsi AGIL dengan kesejahteraan (Gambar 4) menunjukkan bahwa semakin banyak tindakan adaptasi maka semakin tinggi kesejahteraan objektif, sementara fungsi pemeliharaan sistem berkorelasi dengan kesejahteraan subjektif.

Hasil uji korelasi Spearman menunjukkan hubungan yang signifikan negatif antara kesejahteraan objektif dengan kesejahteraan subjektif $(r=-0,260 ; p<0,05)$. Hal tersebut bermakna bahwa, semakin tinggi pendapatan per kapita keluarga (indikator utama kesejahteraan objektif) maka semakin rendah kepuasan (kesejahteraan subjektif) suatu keluarga.

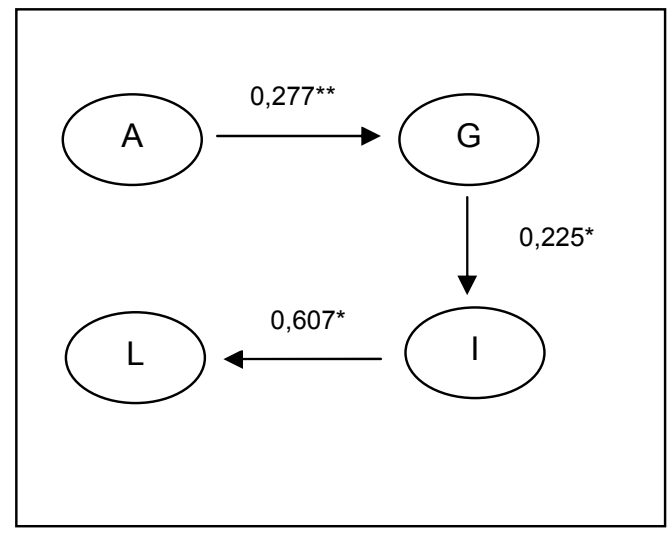

Gambar 3b. Pola hubungan antar fungsi AGIL keluarga petani (Sunarti et al. 2009)

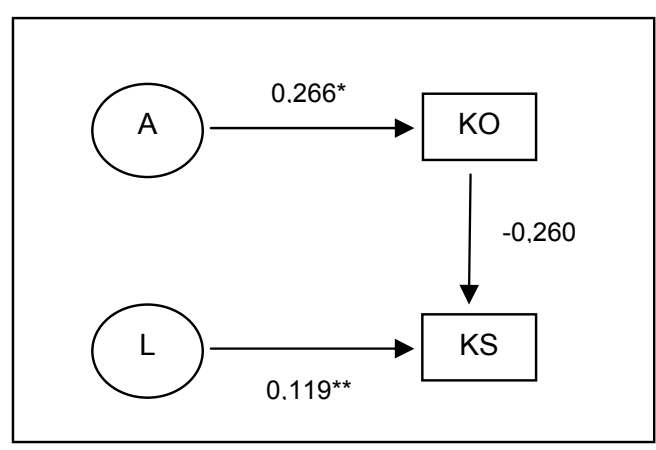

Gambar 4. Pemetaan hasil korelasi bivariat antara fungsi $A G I L$ dengan kesejahteraan keluarga 


\section{KESIMPULAN DAN SARAN}

\section{Kesimpulan}

Penelitian ini memperkaya dan menguatkan penelitian sebelumnya mengenai fungsi $A G I L$ keluarga. Karakteristik contoh menunjukkan sebagian besar juragan dan nelayan memiliki lama pendidikan dibawah 9 tahun, dimana jumlah juragan lebih besar dibandingkan janggol. Pada umumnya dukungan sosial yang diterima juragan dan janggol dari keluarga luas dan tetangga terkategori tinggi, kecuali dukungan dari lembaga/pemerintah dimana juragan memperoleh dukungan yang jauh lebih tinggi dibandingkan janggol. Juragan maupun janggol memiliki akses informasi yang terbatas dengan informasi yang paling banyak diakses adalah info cuaca. Kesejahteraan objektif salah satunya ditunjukkan oleh pendapatan per kapita keluarga. Sebagian besar keluarga juragan dan janggol tergolong sangat miskin pada musim paceklik (saat dilakukan penelitian), namun tergolong tidak miskin pada musim panen. Sementara itu sebagian besar juragan dan janggol memiliki kesejahteraan subjektif yang tinggi. Hasil analisis hubungan menunjukkan lama pendidikan suami, lama pendidikan istri, dan akses informasi berhubungan positif dengan kesejahteraan objektif maupun subjektif. Semakin tinggi kesejahteraan objektif keluarga semakin rendah kesejahteraan subjektif keluarga nelayan.

Hasil analisis hubungan fungsi $A G I L$ menunjukkan pola "A-LGl" dimana semakin baik tindakan adaptasi maka semakin baik pemeliharaan sistem, sementara pemeliharaan sistem berkorelasi dengan integrasi dan tindakan adaptasi keluarga, atau pola "GIL$A$ " dimana semakin banyak tujuan yang ingin dicapai maka semakin baik integrasi dan pemeliharaan sistem, sementara pemeliharaan sistem berhubungan dengan tindakan adaptasi. Tidak terdapat perbedaan fungsi AGIL antara juragan dan janggol, sebelum dan setelah bencana. Hasil analisis antara fungsi keluarga dengan kesejahteraan keluarga menunjukkan bahwa tindakan adaptasi berhubungan dengan kesejahtera- an objektif, sementata kesejahteraan subjektif berhubungan dengan keberfungsian pemeliharaan sistem keluarga.

\section{Saran}

Hasil penelitian ini menyarankan beberapa hal kepada beberapa pihak yaitu: (1) kepada peneliti untuk melakukan penelitian serupa di kelompok masyarakat dengan agroekologi serta mata pencaharian yang beragam; (2) kepada pemerintah daerah serta lembaga/dinas/sektor pembangunan untuk lebih meningkatkan efektivitas program terkait peningkatan ketahanan dan kesejahteraan keluarga atau sebaliknya program pengentasan kemiskinan dan penurunan kerentanan keluarga, khususnya keluarga marjinal; (3) kepada stakeholder penanggulangan bencana untuk meningkatkan program pengurangan risiko bencana, melalui penguatan kelembagaan dan penurunan kerentanan masyarakat di wilayah rawan bencana.

\section{DAFTAR PUSTAKA}

Bakosurtanal. 2009. Badan Koordinasi Survei dan Pemetaan Nasional \& Pusat Studi Bencana UGM. http://www.ppsda.org/_web/index.html. [15 Maret 2009].

Hamilton P. 1983. Key Sociologist Talcott Parsons. England: Ellis Horwood Limited. Tavistock Publications Limited.

Sunarti E. 2007. Theoritical and Methodological Issues on Family Resilience. Makalah disampaikan pada Senior Official Forum on Families, dalam rangka East Asian Ministerial Forum on Families. Diselenggarakan bersama Departemen Sosial, Departemen Luar Negeri, BKKBN, dan Kementerian Pemberdayaan Perempuan. Nusa Dua Bali, 2 September 2007.

Sunarti E, Nuryani N, Hernawati N. 2009. Hubungan antara Fungsi Adaptasi, Pencapaian Tujuan, Integrasi, dan Pemeliharaan Sistem dengan Kesejahteraan Keluarga. Jurnal IImu Keluarga \& Konsumen $2:$ 1-10.

\footnotetext{
* Korespondensi :

Telp : +62-251 8628303

Email : euisnm@gmail.com
} 